https://doi.org/10.30910/turkjans.448368

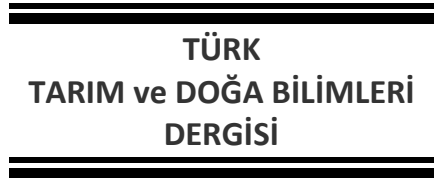

\section{Araştırma Makalesi}

www.dergipark.gov.tr/turkjans
TURKISH

JOURNAL Of AGRICULTURAL

and NATURAL SCIENCES

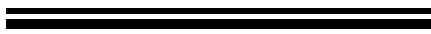

Relationships among Some Quality Characteristics in Broiler Hatching Eggs

\author{
Nezih OKUR*, Sabri Arda ERATALAR, Ahmet YAMAN \\ Bolu Abant Izzet Baysal University, Agriculture and Natural Science Faculty, Poultry Science Department, Bolu \\ Turkey \\ *Corresponding author: nezihokur@ibu.edu.tr
}

Received: 09.11.2017

Received in revised: 04.04.2018

Accepted: 21.05 .2018

\begin{abstract}
Relation among some parameters used for determining egg quality was studied in this research. Egg weight (EW), egg length (EL), egg width (EWd) and shape index (SI) was the studied parameters. A total of 1920 hatching eggs which were obtained from middle-aged (39 week) broiler breeders were used. In the first stage of this study, EW, EL, EWd were measured and SI values were calculated from these parameters. Average EW was $64.40 \pm 0.04 \mathrm{~g}$, EL was $57.35 \pm 1.31 \mathrm{~mm}$, EWd was $44.81 \pm 0.61 \mathrm{~mm}$ and SI was $78.19 \pm 0.10$ in eggs of this study. In the second stage, coefficients of variation, correlation coefficients and regression equations were calculated for determining of relations among these parameters. Significant $(p<0.05)$ and significant correlation levels among EW and EL and EWd were determined ( $r=0.582$ and 0.734 , respectively). Meanwhile, significant and high coefficient correlation among EW and SI was not found $(p>0.05)$ like egg width and egg length. Meanwhile, it was determined that egg width was more important variable than egg length and shape index for estimation of egg weight. Also, it was found that egg weight value could be estimated in higher accuracy by using egg width values instead of egg length and shape index values.
\end{abstract}

Key words: Broiler, hatching egg quality, correlation.

\title{
Kuluçkalık Etlik Piliç Yumurtalarında Bazı Kalite Özellikleri Arasındaki iliş̧kiler
}

\begin{abstract}
Özet
$\mathrm{Bu}$ araştırmada yumurta kalitesinin belirlenmesinde kullanılan bazı özellikler arasındaki ilişkiler araştırımıştır. Yumurta ağırığı (YA), yumurta boyu (YB), yumurta eni (YE) ve şekil indeksi (Şi) bu araştırmada incelenen özellikler olmuştur. Araştırmada orta yaşlı (39 hafta) etlik damızlıklardan elde edilen 1920 yumurta kullanılmıştır. Araştırmanın ilk aşamasında bu yumurtalardaki YA, YB, YG değerleri ölçülmüş ve bu veriler kullanılarak şi değerleri hesaplanmıştır. İkinci aşamada bu özellikler arasındaki ilişkilerin belirlenmesi için varyasyon katsayıları, aralarındaki korelasyon katsayıları ile regresyon denklemi hesaplanmıştır. Çalışılan yumurtalarda YA $64.40 \pm 0.04 \mathrm{~g}$, YB $57.35 \pm 1.31 \mathrm{~mm}$ ve YG $44.81 \pm 0.61 \mathrm{~mm}$ ve şi $78.19 \pm 0.10$ olmuştur. YA ile YB ve YG arasında önemli ( $p<0.05$ ) seviyede bir korelasyon olduğu belirlenmiştir (sırasıyla $r=0.582$ ve 0.734 ). Buna karşılık YA ile şi arasında yumurta eni ve yumurta boyuna benzer şekilde önemli ve yüksek seviyede bir ilişki tespit edilmemiştir. Buna göre, yumurta ağırlığını tahminde yumurta genişliğinin, yumurta boyu ve şekil indeksine göre daha önemli bir değişken olduğu tespit edilmiştir. Ayrıca, yumurta boyu veya şekil indeksi değeri yerine yumurta genişliği değeri kullanılarak yumurta ağırığının daha yüksek bir doğrulukla tahmin edilebileceği bulunmuştur (sırasıyla $53.87 \%, 33.87 \%$ ve $0.08 \%$ ).
\end{abstract}

Anahtar kelimeler: Etlik piliç, kuluçkalık yumurta kalitesi, korelasyon.

\section{Introduction}

Incubation performance is influenced by factors such as egg quality, genetics, breeder age, disease, temperature, humidity, management and feeding conditions in breeders etc. (Kirk et al., 1980, Meijerhoff, 2009; Elibol and Turkoglu, 2014; 
Turkoglu and Sarica, 2014) and is determined by economic criteria such as hatchability. The internal and external quality of the egg is important in both breeder and chick performance (Mc Daniel et al., 1978; Wilson, 1991). Egg weight is an important feature in terms of both incubation and post-hatch performance. It has been reported that hatchability decreases as the egg weight increases (Huwaida et al., 2015). For example, the decrease in heavy (60$65 \mathrm{~g}$ ) and very heavy (> $70 \mathrm{~g}$ ) eggs were found to decrease $5.9 \%$ and $13.5 \%$ respectively compared to medium sized (50 - 60 g) eggs (Kirk et al., 1980). It has been reported to be caused by early (Kirk et al., 1980; Hagger et al., 1986; Rosa et al., 2002; Abiola et al., 2008) or both early and late embryo deaths (Elibol and Brake, 2008) and it was recommended to reduce the temperature after $17^{\text {th }}$ day of incubation for heavy eggs. Also, the egg shape index is an important indicator of egg quality and is expected to be among 72 and 76 in good quality, also is considered as sharp if below 72 and round if above 76 (Sarica and Erensayin, 2014). It has been evaluated to be important to calculate the inter relations among the variables which are hard or expensive to measure (Duzgunes et al., 1983; Kocabas et al., 2013). Hence, to highlight egg quality the inter relations among egg weight, egg width and egg length were evaluated (Kul and Seker 2004; Abanikannda et al., 2007; Aygun and Yetisir, 2010; Rathert et al., 2011; Obike and Azu, 2012; Alkan et al., 2013; Duman et al., 2016). It has been reported that there is a low and significant correlation among shape index and egg weight, despite the high and significant positive correlation among egg weight and egg width. Low and significant $(p<0.05)$ correlation coefficients among shape index and egg weight were found as 0.06 (Alkan et al., 2013), 0.12 (Aygun and Yetisir, 2010) 0.18 (Duman et al., 2016). Also. High and significant correlation coefficients among egg weight and egg width were found as 0.63 (Obike and Azu, 2012), 0.70 (Aygun and Yetisir, 2010), 0.76 (Rathert et al., 2011), 0.80 (Kul and Seker, 2004), 0.80 (Duman et al., 2016), 0.81 (Abanikannda et al., 2007) and 0.86 (Alkan et al., 2013) by different researches. In the light of the studies mentioned, this research was conducted in order to obtain more detailed information about hatching egg quality parameters and relations among these parameters to contribute to the work to be done in this regard.

\section{Material and Methods}

A total of 1920 hatching eggs used in the experiment were collected in the same day and at the same time from a 39-week-old broiler breeder flock of ROSS 308 genotype owned by a commercial company in Bolu. Down-grade eggs were separated, removed from the experiment and the hatching eggs to be set were numbered. The weight of the eggs were measured by precision $( \pm 1 \mathrm{mg}$ ) scale (HZY-2200B; Densi Ltd. Co., Turkey), width and height values were determined by a micrometer (TCM234 990; Tchibo Gmbh, Germany). Then shape index values were calculated by using following formula (Formula 1) which was given by Reddy et al. (1979) and Anderson et al. (2004).

Formula 1. Calculating formula of shape index values.

SI: Shape index; EWd: Egg width; EL: Egg length.

$$
S I=\frac{E W d}{E L} * 100
$$

SPSS 22.0 statistical package program (SPSS, 2013) and formulas were given by Duzgunes et al. (1984) and Kocabas et al. (2013) and was used for analysis data in the study. In first step, Pearson correlation coefficient was calculated to evaluate the relations among properties (Formula 2).

Formula 2. Calculating formula of correlation (Pearson) coefficients on egg weight values.

$$
r_{X Y}=\frac{\sum_{i=1}^{n} X_{i} Y_{i}-\frac{\left(\sum_{i=1}^{n} X_{i}\right)\left(\sum_{i=1}^{n} Y_{i}\right)}{n}}{\sqrt{\left(\sum_{i=1}^{n} X_{i}^{2}-\frac{\left(\sum_{i}^{n} X,\right)^{2}}{n}\right)\left(\sum_{i=1}^{n} Y_{i}^{2}-\frac{\left(\sum_{i}^{n} Y,\right)^{2}}{n}\right)}}
$$

$$
\begin{aligned}
& x=\text { egg weight } \\
& i=\text { egg length } \\
& j=\text { egg width } \\
& k=\text { shape index } \\
& N=\text { number of pairs of scores } \\
& \sum x=\text { sum of egg weight scores } \\
& \sum i=\text { sum of egg length scores }
\end{aligned}
$$

$$
\begin{aligned}
& \sum j=\text { sum of egg width scores } \\
& \sum k=\text { sum of shape index scores } \\
& \sum \mathrm{x}^{2}=\text { sum of squared egg weight scores } \\
& \sum \mathrm{i}^{2}=\text { sum of squared egg length scores } \\
& \sum \mathrm{j}^{2}=\text { sum of squared egg width scores } \\
& \sum \mathrm{k}^{2}=\text { sum of squared shape index scores }
\end{aligned}
$$


After this, coefficient of determination was calculated to find accuracy of predictions and how one variable is predictable from other variables. Egg weight was accepted as main variable and egg length, egg width and shape index were accepted as other variables during this calculations. Then slope of linear regression line (b) and y-intercept point of the regression line (a) values were calculated to following formulas (Formula 3 and 4). Finally, regression equations by regression analyses were calculated for evaluating the relations among properties (Formula 5).

Formula 3. Calculating formula of regression coefficients on egg weight values.

$b=$ Slope of regression line

$x=$ egg weight

$\mathrm{i}=$ egg length

$\mathrm{j}=$ egg width

$\mathrm{k}=$ shape index

$\mathrm{N}=$ number of pairs of scores

$\sum x=$ sum of egg weight scores

$$
b_{x y}=\frac{\sum_{i=1}^{n} X_{i} Y_{i}-\frac{\sum_{i=1}^{n} X_{i} \sum_{i=1}^{n} Y_{i}}{n}}{\sum_{i=1}^{n} X_{i}^{2}-\frac{\left(\sum_{i=1}^{n} X_{i}\right)^{2}}{n}}
$$

Formula 4. Calculating formula of correlation (Pearson) coefficients on egg weight values.

$$
a_{x y}=\frac{\frac{\left(\sum_{i=1}^{n} Y_{i}\right)\left(\sum_{i=1}^{n} X_{i}^{2}\right)-\left(\sum_{i=1}^{n} X_{i}\right)\left(\sum_{i=1}^{n} X_{i} Y_{i}\right)}{n}}{\sum_{i=1}^{n} X_{i}^{2}-\frac{\left(\sum_{i=1}^{n} X_{i}\right)^{2}}{n}}
$$

$\mathrm{a}=$ The intercept point of the regression line and the

$y$ axis.

$x=$ egg weight

$\mathrm{i}=$ egg length

$\mathrm{j}=$ egg width

$\mathrm{k}$ = shape index

$\mathrm{N}=$ number of pairs of scores

$\Sigma x=$ sum of egg weight scores $\sum i=$ sum of egg length scores

$\Sigma j=$ sum of egg width scores

$\sum \mathrm{k}=$ sum of shape index scores

$\sum \mathrm{x}^{2}=$ sum of squared egg weight scores

$\Sigma \mathrm{y}_{i}{ }^{2}=$ sum of squared egg length scores

$\sum \mathrm{y}_{\mathrm{j}}{ }^{2}=$ sum of squared egg width scores

$\sum y_{k}{ }^{2}=$ sum of squared shape index scores

Formula 5. Calculating formula of regression equations on egg weight.

$$
y=a_{i j k}+b_{i j k} x_{i j k}
$$

$\mathrm{y}=$ Egg weight

$a=$ The intercept point of the regression line and the y axis.

$b=$ Slope of regression line

\section{Results and Discussion}

In the first phase of the study, egg weight, egg size, egg width and shape index data of treatment groups were examined in hatching eggs. Egg weight $64.40 \pm 0.04 \mathrm{~g}\left(\mathrm{CV}_{\text {egg }}\right.$ weight $\left.=6.10\right)$, egg length $57.35 \pm 1.31 \mathrm{~mm}\left(C V_{\text {egg }}\right.$ length $\left.=3.56\right)$, egg width $44.81 \pm 0.61 \mathrm{~mm}\left(\mathrm{CV}_{\text {egg width }}=1.21\right)$ and shape index $78.19 \pm 0.10\left(\mathrm{CV}_{\text {shape index }}=8.37\right)$ were found in the eggs used in the study. In the light of this data, it can be said that the uniformity is high, slightly heavy (respectively $64 \mathrm{~g}>60 \mathrm{~g}$ and $64 \mathrm{~g}>63 \mathrm{~g}$ ) to Kirk et al. (1980), and slightly round (respectively $78.19>76.00$ and $(78.19>74.00 \pm 2.00)$ to Sarica and Erensayin (2014). The difference in egg weights $\sum i=$ sum of egg length scores

$\Sigma j=$ sum of egg width scores

$\sum \mathrm{k}=$ sum of shape index scores

$\sum x^{2}=$ sum of squared egg weight scores

$\sum \mathrm{y}_{\mathrm{i}}{ }^{2}=$ sum of squared egg length scores

$\sum \mathrm{y}_{\mathrm{j}}{ }^{2}=$ sum of squared egg width scores

$\sum \mathrm{yk}^{2}=$ sum of squared shape index scores

$$
\begin{aligned}
& i=\text { egg length } \\
& j=\text { egg width } \\
& k=\text { shape index }
\end{aligned}
$$

is also seen in egg width and egg size, indicating a relationship among egg weight, egg length and egg width (Table 1$)$. There was a significant $(p=0.000)$ positive correlation among egg weight and egg size (respectively 0.582 and 0.734 ) and a low negative correlation (-0.029) among egg weight and shape index which is calculated by Pearson correlation coefficient calculating formula $\left(r_{x y}=\left[N \sum x y-\right.\right.$ $\left.(x)(y i j k)] /\left[v\left(\sum x^{2}-\left(\sum x\right)\right) x\left(N \sum y i j k^{2}-\left(\sum y i j k\right)^{2}\right)\right] \times 100\right]$, see the formula 1 for detailed info).

Also higher coefficient of determination was calculated for egg width than egg length and shape index as other parameters. So, accuracy of predictions for egg width $(53.87 \%)$ was higher than 
egg length and shape index (respectively $33.87 \%$ and $0.08 \%$ ).

The results are consistent with the results of researchers reporting that there is a high positive correlation among egg weight and egg width (Kul and Seker, 2004; 2016; Abanikannda et al., 2007; Aygun and Yetisir, 2010; Rathert et al., 2011; Obike and Azu, 2012; Duman et al., 2016; Alkan et al., 2013) and a low correlation among egg weight and shape index (Aygun and Yetisir, 2010; Alkan et al., 2013; Duman et al., 2016). The correlation among egg weight and egg width is higher than Obike and Azu (2012) but lower than Rathert et al. (2011), Kul and Seker (2004), Abanikannda et al. (2007), Alkan et al. (2013), Duman et al. (2016). The correlation among egg length and shape index is lower where it was found to be the opposite by Aygun and Yetisir (2010), Alkan et al. (2013), Duman et al. (2016).

Table 1. Relation between egg weight (EW) and egg length (EL), egg width (EWd), shape index (SI) in broiler hatching eggs.

\begin{tabular}{lcccc}
\hline & & EL & EWd & SI \\
\hline $\mathrm{CV}$ & & 3.56 & 1.21 & 8.37 \\
\hline $\mathrm{R}$ & & & 0.734 & -0.029 \\
\hline $\mathrm{r}^{2}$ & Egg Weight & 0.582 & & \\
& & & 0.5387 & 0.0008 \\
\hline $\mathrm{B}$ & Egg Weight & 0.3387 & & 0.040 \\
& & & 2.630 &
\end{tabular}

Regression Equations (y)

Generally

Egg Weight $=-90.9+0.924 \mathrm{EL}+2.28 \mathrm{EWd}$

\begin{tabular}{|c|c|c|c|c|}
\hline & \multicolumn{3}{|r|}{ 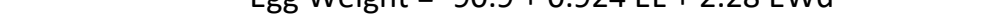 } \\
\hline & & $5.09+1.21 \mathrm{EL}$ & $53.4+2.63 \mathrm{EWd}$ & $67.6-0.040 \mathrm{SI}$ \\
\hline \multicolumn{5}{|l|}{$\mathrm{p}$ Values } \\
\hline & $r$ & 0.000 & 0.000 & 0.197 \\
\hline & $\mathrm{b}$ & 0.000 & 0.000 & 0.197 \\
\hline
\end{tabular}

EL: Egg length; EWd: Egg width; SI: Shape index; CV: Coefficient of variation; $r$ : Correlation Coefficient; $r^{2}$ : Coefficient of determination, b: Regression coefficient.

\section{Conclusion}

Egg weight (EW), egg length (EL), egg width (EWd) and shape index (SI) values, with their inter relations were investigated in hatching eggs obtained from middle aged broiler breeders. It has been determined that there was a significant and high level relationship among EW and EWd, EWd ( $r$ $=0.582$ and 0.734 respectively). Correlation among EW and EWd were higher than the correlation among any other parameters. At the same time, relation among EW and $\mathrm{SI}$ was found not to be significant at a high level. According to this data, it can be said that egg width is an important variable for estimation of egg weight. Therefore egg weight values can be estimated by egg width values with higher accuracy than it can be done by egg length and shape index values.

When the results of the research were evaluated in general, it was found that there was a high and significant relation among EW, EL and EWd and these results were found to be consistent with the results of other researchers. It is also believed that monitoring these effects on post-hatch performance of chicks and organizing more detailed, comprehensive research is needed and will be beneficial for both academic and industrial evolution.

\section{Acknowledgement}

This study was carried out under the research project that is funded with the decision taken by Bolu Abant Izzet Baysal University Scientific Research Projects Committee (Project No. 2016.10.03.1029, 14 March 2016). We thank to BAIBU for this financial support and Beypi Inc. (Beypiliç ')'s for supply research material.

\section{References}

Abanikannda, O.T.F., Olutogun, O., Leigh, A.O., Ajayi, LA. 2007. Statistical modeling of egg weight and egg dimensions in commerical layers. International Journal of Poultry Science, 6: 59-63.

Abiola, S.S., Meshioye, O.O., Oyerinde, B.O., Bamgbose, M.A. 2008. Effect of egg size on hatchability of broiler chicks. Archivos de Zootecnia, 57: 83-86.

Alkan, S., Karsli, T., Galic, A., Karabag, K. 2013. Determination of phenotypic correlations between internal and external quality traits of guinea fowl eggs. Journal of Faculty of Veterinary Medicine Kafkas University, 19: 861-867. 
Anderson, K.E., Tharrington, J.B., Curtis, P.A., Jones, F.T. 2004. Shell characteristics of eggs from historic strains of single comb white leghorn chickens and relationship of egg shape to shell strength. International Journal of Poultry Science, 3: 17-19.

Aygun, A., Yetisir, R., 2010. The Relationship among egg quality characteristic of different hybrid layers to forced molting programs with and without feed withdrawal. Journal of Animal and Veterinary Advances, 9: 710-715.

Duman, M., Sekeroglu, A., Yildirim, A., Eleroglu, H., Camci, O. 2016. Relation between egg shape index and egg quality characteristics. European Poultry Science, 80: 1-9.

Duzgunes, O., Kesici, T., Gurbuz, F. 1983. Statistical Methods. Ankara University Press, Ankara.

Elibol, O., Brake, J. 2008. Effect of egg weight and position relative to incubator fan on broiler hatchability and chick quality. Poultry Science, 87: 1913-1918.

Elibol, O., Turkoglu, M. 2014亡. Embryo Development and Hatchery. Poultry Science (EDs M. Turkoglu and M. Sarica), Bey Ofset, pp. 200206.

Hagger, C., Steiger-Stafl, D., Maguerat, C. 1986. Embryonic mortality in chicken eggs as influenced by egg weight and inbreeding. Poultry Science, 65: 812-814.

Huwaida, E.E., Sakin, M.A.I.Y., Elagib, H.A.A., Bakhiet, E., Dousa, B.M., Elamin, K.M. 2015. Effect of egg weight and egg shell thickness on hatchability and embryonic mortality of Cobb broiler breeder eggs. Global Journal of Animal Science Researches, 1: 186-190.

Kocabas, Z., Ozkan, M., Baspinar, E., 2013. Basic Biometry. Ankara University Press, Ankara.

Kirk, S., Emmans, G.C., Mc Donald, R., Arnot, D. 1980. Factors affecting the hatchability of eggs from broiler breeders. British Poultry Science, 21: 37-53.

Kul, S., Seker, I. 2004. Phenotypic correlations between some external and internal egg quality traits in the Japanese quail (Coturnix coturnix japonica). International Journal of Poultry Science, 3: 400-405.

Mc Daniel G.R., Roland D.A., Coleman M.A. 1978. The effect of egg shell quality on hatchability embryonic mortality. Poultry Science, 58: 1013.

Meijerhof. R. 2009. The influence of incubation on chick quality and broiler performance. $20^{\text {th }}$ Australia Poultry Science Symposium, 9-11 February, New South Wales, Sydney, Australia.

Obike, M.O., Azu, K.E. 2012. Phenotypic correlations among body weight, external and internal egg quality traits of pearl and black strains of guinea fowl in a humid tropical environment. Journal of Animal Science Advances, 10: 857864.

Rathert, T.C., Uckardes, F., Narinc, D., Aksoy, T., 2011. Comparison of principal component regression with the least square method in prediction of internal egg quality characteristics in Japanese quails. Journal of Faculty of Veterinary Medicine Kafkas University, 17: 687-692.

Reddy, P.M., Reddy, V.R., Reddy, C.V., Rap, S.P. 1979. Egg weight, shape index and hatchability in khaki Campbell duck egg. Indian Journal Poultry Science, 14: 26-31.

Rosa, P.S., Guidoni, A.L., Lima, I.L., Bersch, F.X.R. 2002. Effect of incubation temperature on hatching results of broiler breeders' eggs classified by weight and hen age. Brazilian Journal of Poultry Science 31: 1011-1016.

Sarica, M., Erensayin, C. 2014. Poultry Products. Poultry Science (EDs M. Turkoglu and M. Sarica), Bey Ofset, pp. 89-138.

SPSS, 2013. SPSS Release 22.0 Statistical packet program, SPSS for Windows. SPSS Inc., Chicago, IL, USA.

Turkoglu, M., Sarica, M. 2014. Breeder Management. Poultry Science (EDs M. Turkoglu and M Sarica), Bey Ofset, pp. 344350.

Wilson, H.R. 1991. Interrelationships of egg size, chick size, posthatching growth and hatchability. World's Poultry Science Journal, 47: 5-20. 